\title{
MARCAS DO GENOCÍDIO NA LITERATURA DE RESISTÊNCIA DE MULHERES INDÍGENAS DE ABYA YALA
}

\author{
GENOCIDE MARKS IN THE INDIGENOUS \\ WOMEN'S RESISTANCE LITERATURE OF \\ ABYA YALA
}

\author{
Larissa Fontinele de Alencar ${ }^{1}$ \\ [https://orcid.org/0000-0003-3190-9279] \\ Tânia Maria Sarmento - Pantoja² \\ [https://orcid.org/0000-0003-1575-5679] \\ DOI: 10.30612/raido.v15i38.14865
}

RESUMO: Este artigo aborda as marcas do genocídio presentes em textos literários de autoria de mulheres indígenas de Abya Yala, como se convencionou designar o continente americano pelos povos originários. Inicialmente, apresentamos um breve panorama contextual sobre as questōes referentes ao genocídio dos povos originários desde a invasăo dos europeus no período da colonizaçăo e como este fato histórico nos conduz até a contemporaneidade, em que as colonialidades se fazem presente em diversos âmbitos. Também traçamos alguns apontamentos sobre as literaturas de resistência de autoria de mulheres indígenas, para na sequência final analisarmos as escrituras de seis autoras das etnias Mapuche, Potiguara e Maya, sob a ótica da análise literária identificando as nuances das palavras que representam o genocídio indígena através dessas vozes femininas.

Palavras-chave: Resistência. Genocídio. Literaturas. Indígenas.

ABSTRACT: This article discusses the marks of genocide present in literary texts authored by indigenous women of Abya Yala, as it was convinced to designate the American continent by the original peoples. Initially, we present a brief contextual overview of the issues related to the genocide of the original peoples since the invasion of Europeans in the period of colonization and how this historical fact leads us to contemporaneity, in which colonialities are present in various areas. We also trace a brief path of the resistance literature singed by indigenous women, so that in the final sequence we analyze the scriptures of six authors of the Mapuche, Potiguara and Maya ethnic groups, from the perspective of literary analysis identifying the nuances of the words that represent indigenous genocide through these female voices.

Keywords: Resistance. Genocide. Literature. Indigenous.

\footnotetext{
1 Universidade Federal do Pará (UFPA)

2 Universidade Federal do Pará (UFPA).
} 


\section{INTRODUÇÃO}

Awya Yala Wawgeykuna

Awya yalla apachi q'osni patapi

Tawa K'uchu tawantinsuyumanta

Yawar qhocha kutipun

llajsakun sirch'i nina urqota.

Hermanos Americanos

Abya Yala sobre las aras humeantes

Los cuatro puntos cardinales

Se tornan infiernos de sangre

Lava incandescente funde su potencia.

(TUPTURKA, 2017, p. 10)

O excerto poético é a primeira estrofe referente ao poema Abya Yala Wawgeykuna (Hermanos Americanos), escrito por Tupturka, originário do povo Quechua da Argentina, ganhador do Certamen Nacional de Cuento y Poesía "Grupo Icthios", em 1990. O poema, escrito em quéchua e traduzido para o espanhol, faz uma convocaçăo a todos os povos originários, irmanados por habitar terra e por opressôes sofridas no processo de colonizaçăo, transformem-se a força ancestral em potência literária, apesar dos infernos de sangue, da lava incandescente de tantas mortes, destruiçáo, extermínio de identidades e tantas outras atrocidades.

Partindo desse pressuposto poético, o objetivo deste artigo é observar alguns poemas sob o prisma das literaturas de resistência de autoria mulheres indígenas a partir da perspectiva dos traços do genocídio dos povos originários de Abya Yala. De acordo com o geógrafo Carlos Walter Porto-Gonçalves (2009), Abya Yala é uma autodesignaçăo dos povos originários do continente em oposiçăo a palavra América. É uma palavra de origem do povo kuna que significa Terra Madura. Levando em conta que as organizaçôes e instituiçôes de povos originários adotaram esse nome comum para se referir a terra continental ancestral dos povos, devemos considerar que é um símbolo de identidade e respeito pela terra habitada, diferentemente da nomenclatura América que exalta o colonizador, essa expressăo marca um posicionamento político de produzir sentidos ancestrais e anticoloniais.

De todo modo, a situaçăo atual dos mais de 600 povos indígenas que habitam essas terras é o resultado do processo histórico que começou a mais de cinco séculos, em 1492, com o encontro fatídico dos europeus ao chegarem com o discurso despretensioso de uma busca de rotas alternativas para o comércio com o continente asiático, que logo se tornou um discurso genocidário de desvalia dos povos originários. Gradualmente "descobriram" um continente inteiro, superpopuloso e habitado por uma diversidade de grupos étnicos, a quem denominaram erroneamente de "índios", ao considerá-los supostamente como habitantes da Índia.

Graciela Huinao, poetisa de origem Mapuche, em Salmo 1492, poetiza o fatídico ano. Graça Graúna, escritora Potiguara, conta em poema sobre o pernil de carneiro 
retalhado que se transformou em Abya Yala. A poetisa maya, Briceida Cuevas Cob, nos conta da coruja que anuncia a morte. Estas e outras vozes contemporâneas se somam aos cantos poéticos de resistência das mulheres indígenas destas terras continentais que regou as sementes ancestrais com muito sangue originário.

Portanto, encontro marcado pelas opressóes, espoliaçôes de todas as ordens e morte massiva, encontro de genocídio contra os corpos, contra as epistemes milenares e de tentativa de extermínio das ancestralidades está calcado através da palavra na literatura feitas por várias mulheres indígenas dos povos originários. Assim, é diante das ressignificaçóes da resistência, a partir de um olhar de quem sente as dores e tem as cicatrizes marcando a alma por um trauma colonial, que observaremos a poesia indígena.

\section{BREVE PONDERAÇÃO HISTÓRICA SOBRE O GENOCÍDIO INDÍGENA EM ABYA YALA}

É inconteste que as colonizaçōes europeias provocaram um dos maiores atentados contra a humanidade, ao desumanizarem os habitantes das terras recém tomadas, os portugueses, espanhóis, ingleses e outros buscaram formas de validar a dizimaçăo dos povos originários, utilizando discursos religiosos cristâos para promover o massacre dos nativos e a posse das suas terras, privando-os da liberdade, limitando-os a serem considerados apenas como animais: excluindo-os de dignidade e menosprezando-os por suas formas de pensar e agir diferentes do ideário europeu.

A respeito desse morticínio indígena, a antropóloga indigenista brasileira Manuela Carneiro da Cunha acrescenta ganância e ambiçăo como forma de impulso aos severos atos de colonizaçăo: "Este morticínio nunca visto foi fruto de um processo complexo, cujos agentes foram homens e microorganismos, mas cujos motores últimos poderiam ser reduzidos a dois: ganância e ambiçâo, formas culturais da expansâo do que se convencionou chamar de capitalismo mercantil" (CUNHA, 2002, p.12). Segundo a antropóloga, dados nos revelam que um pequeno número de colonizadores armados de pólvora bastou para tornar exitosos os seus crimes contra um continente abundantemente povoado, estima-se que de 1 milhăo a 8,5 milhóes de nativos habitavam as terras baixas da América do Sul na época da chegada dos europeus.

As atrocidades dos processos de colonizaçăo nas Américas sâo inumeráveis, dizimaçâo de comunidades inteiras, a promoçâo do aniquilamento da cultura e a imposiçâo religiosa foram brutalmente capazes de negativar saberes ancestrais, genocídios agregados de saberes destruídos pela lógica colonial-capitalista. Complexo projeto colonial de extermínio dos povos originários que permanece até a contemporaneidade, com vários aspectos que subjazem um ideário de necropolítica, como diz o filósofo africano Achille Mbembe (2018), que reflete sobre a vida e a morte diante de contextos coloniais e neocoloniais. A partir disso, o estudioso tece a discussăo sobre as heranças históricas na contemporaneidade envolvidas nas práticas de dominaçăo do Estado, através de discursos e práticas excludentes de uma política que reverbera morte em um estado genocidário que se perpetra por todo o continente, e que tende ser ainda mais duro para as mulheres indígenas. Enfim, o trauma colonial năo cessa de se articular sob as novas faces da Modernidade/Colonialidade. 
É urgente pensarmos sobre essas questôes nos estudos literários para ampliarmos os estudos da resistência para o campo da autoria indígena, compreendendo como se dá os processos de barbárie que culminam na permanência do trauma, neste caso, uma barbárie perpetrada por colonizadores que se instaurou na história seguinte a colonizaçăo como uma cicatriz ainda aberta.

Quando se trata de conceituar essa palavra "genocídio" há uma tendência em pensarmos somente no Holocausto nazista da Segunda Guerra Mundial provocado contra o povo judeu, no entanto, as práticas genocidárias fazem parte da humanidade. No entanto, talvez um dos maiores atos de barbárie que já ocorreu na história se deu com o projeto colonial do continente americano que ultrapassa períodos, náo se manteve ao tempo que durou a colonizaçăo, muito pelo contrário se fortaleceu ainda mais com a subjugaçăo dos corpos diferentes do corpo colonizador. Como diz o sociólogo peruano Anibal Quijano:

O fato é que já desde o começo da América, os futuros europeus associaram o trabalho năo pago ou năo-assalariado com as raças dominadas, porque eram raças inferiores. $O$ vasto genocídio dos índios nas primeiras décadas da colonizaçăo năo foi causado principalmente pela violência da conquista, nem pelas enfermidades que os conquistadores trouxeram em seu corpo, mas porque tais índios foram usados como mâo de obra descartável, forçados a trabalhar até morrer. (QUIJANO, 2005, p. 120)

Essa observaçâo é de suma importância para entendermos que o genocídio durante a colonizaçăo năo esteve presente somente nas chamadas "Guerras da conquista" por territórios, mas, sobretudo, através do trabalho forçado em que os indígenas eram levados à extrema exaustăo até à morte. Trata-se de projeto colonial genocidário que agiu em várias frentes: no extermínio literal dos povos, no abrandamento das culturas, na docilizaçâo dos corpos indígenas através do uso da religiăo hegemônica, enfim, uma a(mal)gamado de contextos.

A escritora indígena Eliane Potiguara em uma parte da sua obra Metade cara, metade máscara, trata sobre a separaçăo violenta das famílias dos territórios imemoriais dos povos indígenas como impulsionadora do trauma colonial: "Isso provocou insegurança familiar, distúrbios, medo e pânico, causando loucura, violências interpessoais, suicídios, alcoolismo, timidez e a baixa autoestima diante do mundo" (POTIGUARA, 2018, p. 20). Ao separar uma família, retirar de seu território e obrigar uma imigraçăo, para a autora, dissipa-se a cultura e os elos com a ancestralidade; quebrar esse vínculo é uma das formas de apagar a história da descendência e homogeneizar todos com sendo pertencentes a uma única naçăo.

Similar ao relato de Potiguara, a narrativa oral de uma das avós da ativista Moira Millan pertencente ao grupo étnico Mapuche, denuncia a presença de campos de concentraçâo que detinham mulheres e crianças somente por serem mapuche, nesses lugares se cometiam inúmeras atrocidades. Nos relatos se vê mulheres enlouquecidas pelas crueldades praticadas pelos capatazes: filhos que săo dados aos cachorros para servirem de comida, maridos degolados em frente às suas esposas, săo barbáries cometidas com o consentimento do estado.

Una de ellas mi abuela Selmira Práfil, quien recordaba los siguiente: “...dicen que lo winka llegaban a los tiros, disparaban contra toda la gente mapuche, así dice que 
quedo mi tía loca, pofo taba la pobre tía, que dicen que tenía su bebé recién nacido y como estaba débil por el parto y casi ni comían los mapuches porque los winka les negaban la comida se iban enfermando y muriendo en el camino, así dice que ella iba bien mal con su hijito meta llorar, arrastraba el pié pa caminar, y retrasaba a toda la gente entonces vino un winka que estaba a caballo, un soldado y le pidió su bebe, y ella se lo dio porque pensó que iba a llevarlo por delante en el caballo, y el soldado tiró la criatura los perros que tenían, dicen que tenían mucho perro bien malo que usaban para cazar a los mapuche y así lo mataron al hijo de la tía a mordiscones, la tía se volvió loca después de eso...". (MILLÁN, 2011, p. 131 - 132)

O Winka, em mapudugum, língua originária mapuche, significa o năo-mapuche, ou seja, no período da colonizaçấo o branco, o europeu que cometia as piores atrocidades contra os grupos originários. Năo se pode mensurar o quanto de sofrimento e trauma carregam os nativos de Abya Yala, sáo relatos de profunda dor, que deixam marcas no corpo, na descendência e transparecem nas escrituras.

Assim, o engenhoso e perverso projeto colonial chega a pretensa modernidade a partir dessa dissipaçăo de saberes ancestrais, mas que por resistência podem ser retomados. Rastros apagados também poderáo ser restaurados para o reencontro com a ancestralidade, como veremos nos poemas de mulheres indígenas de Abya Yala que foram selecionados para compor este artigo.

\section{RESISTÊNCIA E AS LITERATURAS INDÍGENAS DE AUTORIA FEMININA}

Pela palavra literária dos povos originários também se fazem as literaturas de resistência, uma vertente dos estudos literários que trata sobre os textos dentro do âmbito de situaçóes de violência, autoritarismo, opressáo, que perpassam tanto os contextos históricos em que esses textos estâo inseridos quanto as temáticas que emergem deles. De acordo com a pesquisadora estadunidense Barbara Harlow, as literaturas de resistência, em um contexto teórico-histórico, "chama a atençâo para si e para a literatura em geral como uma atividade política e politizada. A literatura de resistência se vê ainda mais imediata e diretamente envolvida em uma luta contra formas ascendentes ou dominantes de produçâo ideológica e cultural" (HARLOW, 1987, p.28).

Assim, as organizaçôes de resistência representam uma luta da coletividade contra a dominaçấo. A pesquisadora utiliza o termo literatura de resistência para definir textos literários que possuem características que estáo envoltas na ideia de luta contra opressấo e que, por sua vez, sâo marginalizados por năo fazerem parte da cultura hegemônica. De modo geral, a literatura de resistência é um produto escrito que advém dos conflitos políticos entre o Colonialismo/Modernidade e os movimentos de resistência nativos.

Diante desse conceito, as resistências nas artes estăo atreladas às escolhas temáticas e formais, assim como estâo aliadas à imagem de insistência e de contraposiçăo a uma força que está fora do autor e sua obra. Desta forma, implica também em, como diz o teórico da literatura brasileira Alfredo Bosi, um "nâo lançado à ideologia dominante" (BOSI, 2002, p. 129). Deste modo, literatura de resistência é uma literatura relacionada ao teor político que a compóe, que nâo precisa encontrar-se explicitamente engajado, 
mas que contém um teor de contraposiçăo a uma ordem dominante, tanto na esfera literária, quanto no âmbito histórico e sociocultural.

Diante disso, consideramos as literaturas feitas pelas mulheres dos povos originários como uma possibilidade de observaçáo e ressignificaçâo da literatura de resistência. Por isso, é importante fazermos o percurso que nos encaminha para as situaçôes de barbárie que envolvem, de modo geral, os povos originários de Abya Yala.

É necessário ressaltarmos que, ao se tratar de literaturas indígenas, as definiçóes e os conceitos esbarram, como bem pondera a escritora de origem potiguara Graça Graúna, "no preconceito literário estampado no mascaramento de polêmicas doutrinais. No cânone, essa literatura náo aparece mencionada; seu lugar tem sido, até agora a margem. Poucos se dâo conta de sua pulsaçăo." (GRAÚNA, 2013, p. 55). A palavra-flecha indígena resiste e traspassa o tempo, evoca a memória, a identidade e as ancestralidades. Graça Graúna, que além de escritora também é estudiosa da literatura, nos alerta que entre os indígenas a palavra é um elemento sagrado, "[...] palavra e identidade se confundem; palavra que passa de pai para filho, dos avós para os netos; palavra carregada de água, palavra vinda da terra, palavra aquecida pelo fogo, palavra tăo necessária quanto o ar que se respira; palavra que atravessa o tempo". (GRAÚNA, 2013, p.173).

É importante, observamos o que pondera a pesquisadora dos estudos literários ameríndios, a professora Rita Olivieri-Godet, sobre a resistência da palavra enunciada pelas vozes literárias de mulheres de Abya Yala, mais especificamente, sobre brasileiras e canadenses, originárias de dois polos de Abya Yala:

[...] levantam sua voz e aproximam as duas extremidades do continente graças à sua
criaçáo literária. Seu discurso poético reaviva a memória de sua ancestralidade e
lembra nossa história compartilhada, inscrita nas marcas da violência do genocídio
contra os povos ameríndios, experiência comuma todos os processos de formaçáo dos
Estados nacionais do continente. As obras dessas escritoras fissuram o imaginário
colonizado sobre o espaço das Américas, reanimando a memória ancestral da
ocupaçăo do território pelos povos autóctones. (OLIVIERI - GODET, 2020, p. 20).

É sob essa fissura do imaginário colonizado, como uma fresta de resistência, que as literaturas dos povos originários se movem, para Olivieri-Godet (2020) os textos poéticos podem abrir espaços ao engajamento político e chamar à resistência, afinal, o texto poético é um canto de denúncia e de revolta contra o declínio dos mundos dos grupos étnicos. "Memória dos massacres, da humilhaçáo, da despossessăo, traduzida em palavras duras para que todos se lembrem: 'Eu me lembro / de ter sido desonrada / esfolada / deformada / agredida / sangrada / violentada' (Kanapé Fontaine, 2016, p. 68)". (OLIVIERI-GODET, 2020, p.118). Ao referir-se aos textos da escritora do povo originário innu Kanapé Fontainne, a pesquisadora reflete que as escritoras instauram seu próprio espaço de enunciaçấo, privilegiando a problematizaçăo de sua identidade de mulheres e ameríndias, além de suas relaçôes com as sociedades ocidentais através da face mais perversa do colonialismo: a tortura e a morte.

Essas vozes ameríndias reverberam um grito de resistência frente aos desmandos e ecos do colonialismo, culminado em um trauma colonial proveniente do genocídio perpetrado de Norte a Sul de Abya Yala. Como observaremos um pouco mais no próximo 
tópico para percebermos as nuances bem demarcadas das opressóes vivenciadas pelas mulheres indígenas do continente.

\section{GENOCÍDIO EM ESCRITURAS DE MULHERES INDÍGENAS POTIGUARA, MAPUCHE E MAYA}

A colonizaçăo europeia em nosso continente foi um processo histórico catalisador da morte de milhares de indígenas, além da tentativa de extermínio da ancestralidade daqueles que permaneceram vivos e puderam repassar de geraçăo em geraçăo as suas culturas. As literaturas indígenas na contemporaneidade marcam ancestralidade e morte como ressignificaçăo através da resistência da palavra, como arma de libertaçăo das opressóes e como grito que reverbera os cantos ancestrais dos quéchuas, nahuas, tupi-guaranis, mapuches, aymaras, potiguaras, macuxis, kambebas, innues, mayas e tantas outras manifestaçóes de existências que foram apagadas pela Modernidade/ Colonialidades, porém nunca perdidas.

Apesar dos pesares da colonizaçâo genocidária, as literaturas indígenas vivem na contemporaneidade um florescer crescente de consolidaçaáo das vozes de mulheres indígenas. Para esta análise literária selecionamos três grupos étnicos distintos de pontos variados de Abya Yala: os Mapuche, que habitam parte do território do sul do Chile e parte da Argentina, estâo representados pelas escritoras Graciela Huinao e Rayen Kvyeh; os Potiguara, grupo étnico brasileiro que está territorializado em uma pequena contingência de terra do estado da Paraíba, litoral do nordeste brasileiro, representados pelas autoras Eliane Potiguara e Graça Graúna; e o povo indígena Maya, representado pelas escritoras Briceida Cuevas Cob (México) e Rosa Chávez (Guatemala).

É importante assinalar que há muito mais que 600 grupos étnicos espalhados como sementes por este território de Abya Yala, esta amostragem de apenas seis mulheres de três grupos étnicos é apenas um pinçar de excertos poéticos que tocam em uma das questôes de maior relevância entre todos os povos indígenas: as marcas cruéis dos genocídios dos povos originários. A seleçâo de autoras problematiza desde a sua relaçáo com o ser indígena quanto a sua condiçăo de gênero, demarcadores de espoliaçóes sistemáticas.

Notadamente as escritoras indígenas ecoam vozes ancestrais, as de origem Mapuche como Graciela Huinao e Rayen Kvyeh, de modo geral, tensionam o canto ancestral e recriam a partir de elementos da sua própria história de luta, do passado que se reflete no contemporâneo, ressignificando conexōes com a memória de dores e mortes com cantos sagrados. É diante desse contexto de cosmovisăo e da história de resistência do povo Mapuche, que o eu-lírico de um dos poemas mais difundidos de Huinao, intitulado Salmo 1492, se converte em resistência:

SALMO 1492

NUNCA FUIMOS

EL PUEBLO SEN̂ALADO

PERO NOS MATAN

EN SEN̂AL DE LA CRUZ.
SALMO WARANKA, MELI PATAKA, AILLA MARI EPU TURPU NGÜNEL TROKIŃCHENOFEL IŃCHIŃ WELU LANGÜMNGEKEIN̂

KÜRUZ ÑI DUAM MEU.

(HUINAO, 2009, p.20) 
Com forma poética condensada, formado por uma estrofe e quatro versos simples, Huinao revela as formas que a tradiçâo religiosa cristấ colaborou para estigmatizaçáo do seu povo originário Mapuche, assim como, de tantos outros povos. Originalmente associado ao cântico sagrado do Antigo Testamento, o Salmo é usado como ironia ao discurso judaico - cristâo, hegemônico e destrutivo da cultura, da episteme dos povos originários. O ano de 1492 é marcado pelo pretensioso "descobrimento" das "Américas" por Cristóvâo Colombo, é a partir daí que a espoliaçăo dos povos originários inicia, sob a máscara do Cristianismo, formando uma colonizaçăo baseada no genocídio das populaçôes originárias, que perdura sob novas nuances de extermínio. Enfim, estar assinalado pelo sinal da Cruz, no poema, é estar marcado pelo símbolo da morte, um povo assinalado para morrer e náo para viver os gozos da vida eterna.

O micro poema joga com a simbologia ironicamente perversa de elementos que compóem os sinais do genocídio, marcas colonizadoras do Cristianismo unidas às marcas de aniquilamento. Os quatros versos esgarçam o véu do que representou a ascensăo da religiăo através da marca indelével da morte: torturas em nome da redençăo eterna, ou o fim da vida ou a conversâo, que é a morte das origens em si. Assim, estar marcado pela cruz significa para além da própria morte, a morte da cultura originária.

Em outro texto denominado El Patas Verdes, de Graciela Huinao, desta vez uma narrativa de tom testemunhal, mostra as marcas de violência extrema. Apenas à mençâo ao nome do genocida, o medo se propagava:

La muerte y él fueron yunta, la maldad lo amarró a ese yugo y como no tuvo bandera, el odio fue su escudo al ampararse en su cruzada de violación. La sola mención de su nombre, el miedo se volvía plaga, echaba abajo las puertas de territorio williche, infectando a toda la comunidad. (HUINAO, 2006, p. 36)

Huinao mostra a violência, estupro e vingança ao contar a história de Patas Verdes (un monstruo, engendrado en España y parido en el sur del mundo), o estuprador da avó que foi torturada aos 12 anos, (La maldición cayó en mi sangre, cuando mi abuela tenía doce años). As marcas da violência săo carregadas na hereditariedade, após o evento traumático carregará o filho daquele violador em seu ventre. Săo histórias de violaçōes contra as mulheres que se repetem em muitas comunidades indígenas de Abya Yala. Nesse texto, o dever da memória emerge como um mandato para nâo esquecer ou lembrar de fazer justiça/vingança ao crime silenciado, já que sob as vias legais, năo há puniçăo aos colonizadores pelas atrocidades cometidas. As marcas do genocídio do povo originário mapuche williche através da figura do capataz Patas Verdes, um ser sem bandeiras, sem identidade que teve o ódio como seu principal impulsionador.

A escritora mapuche Rayen Kvyeh, no poema Colonización, prenuncia presságios de morte que sâo seguidos de caravelas ao mar contra os filhos da terra, sob a égide imperial de canhóes:<smiles>[AlH2]</smiles>

Um río de sangre que emana desde el norte como um huracán atraviessa el continente hasta el confín de la tierra. 


\author{
Cortan las vísceras \\ de las hijas de la tierra \\ en violaciones que inmolan \\ la cruz y el império [...] \\ (KVYEH, Rayen, apud Curriao \& García, 2010, p. 183-185)
}

Marcas da morte, do sangue derramado, de massacres e extermínios contra grupos étnicos e contra os corpos das mulheres que formam a imagem de um rio de sangue atravessando todo o continente. Metáfora que evidencia um morticínio de devastaçáo de gentes. Mais adiante, na última estrofe, o poema também faz clara referência às violaçôes ao corpo de mulheres indígenas promovidas pelo projeto genocidário colonial: "Salvajes manos de ojos de acero/ del winka invasor / cortan las vísceras / de las hijas de la tierra / en violaciones que inmolan / la cruz y el império" (KVYEH, apud Curriao \& García, 2010, p.183). A representaçấo da Cruz e do Império como marcas inapagáveis de uma simbologia do domínio colonial que promove o morticínio em nome do poder. Tudo isso săo marcas genocidárias que se fazem potentes de sentidos e visíveis aos nossos olhos a partir de um processo de resistência, sobretudo, de resiliência que busca ressignificar dores traumáticas.

Ancestralidade é palavra-chave da resistência indígena presente nesses textos literários. A memória afetiva se efetiva através dos corpos de mulheres dos povos originários de Abya Yala. No poemário de Eliane Potiguara, observamos que năo há apenas uma mulher indígena, condensada em sua autoria há toda uma coletividade representada pelo "nós" que carregam o peso da violência, da exclusăo, da morte, marcas do genocídio feito pelo colonizador. Como ressoa em seu poema Identidade indígena:

\author{
Nosso ancestral dizia: Temos vida longa! \\ Mas caio da vida e da morte \\ E range o armamento contra nós. \\ Mas enquanto eu tiver o coraçăo aceso \\ Năo morre a indígena em mim e \\ E nem tampouco o compromisso que assumi \\ Perante os mortos \\ De caminhar com minha gente passo a passo \\ E firme, em direçáo ao sol. \\ $[\ldots]$ \\ Porque temos o coraçăo pulsando \\ Jorrando sangue pelos quatro cantos do universo. \\ Eu viverei 200, 500 ou 700 anos [...] \\ (POTIGUARA, 2018, p 113)
}

O sangue jorrado dos mortos é impulsionador da ancestralidade. É através dele que nas veias se revigoram a identidade, é no seu derramamento, em sofrimento, que 
as dores do genocídio reverberam pelo poema, em palavras de resistência. Potiguara metaforiza a resistência através do clamor poético para cessarem as violências contra as formas de expressáo indígena. Ao metaforizar, em seu canto profundo de ancestralidade, as raízes e as sementes que resistem ao serem fecundadas pela terra, nos mostra que é impossível apagar os rastros da memória e, assim, dar passos firmes em direçâo ao sol, ao futuro, à plenitude, porque há vida, "vida longa!", apesar dos desenganos, há esperança na coletividade: "coraçăo pulsando / jorrando sangue pelos quatro cantos do universo".

O caos das buscas pelo território, as espoliaçōes provocadas pelas guerras, além dos estupros das mulheres indígenas e dos deslocamentos forçados, pretendemos analisar a ressignificaçăo poética das escritoras Maya Rosa Chávez Juárez (Maya kiché-kaqchikel, Guatemala) e Briceida Cuevas Cob (Maya yucateca, México).

Briceida Cuevas Cob é uma das mais conhecidas escritoras mayas mexicanas, o poema intitulado El buho introduz a antologia poética Del dobladillo de mi ropa (2008) e abre com sonoridade própria o canto que será conduzido pelo decorrer do livro. Tratase de uma composiçấo curta, apenas 11 versos em um jogo rítmico, bem cadenciado na língua maya, que avança junto com a atmosfera que o poema dedicado a ave Coruja constrói. El búho, a coruja, é um pássaro naturalmente notívago e simbolicamente está atrelado aos mistérios e soturnidade da escuridâo da noite, quase sempre ligado à sabedoria e à morte. Nota-se a cadência das vogais da língua original que remetem ao canto da coruja, nos induz a uma espera pelo desvelar de um enigma, o presságio da morte. A voz poética diz:

Xooch'
Ts'o'ok u k'uchul xooch'.
Tu mot'ubal yo'koot.
T'uubul tu tuukul
Máax ken u tomojchi'it
wa mix máak ku k'iin ti' le kaaja'.
U xla' báakel máako'obe' chen ka
máanako'ob.
Uje' tu bonik u muknalilo'ob
ch'een k'aax
ts'o'ok u káajal u lu'uk'ul tumen
loobil.
Xooch'e'
tu xuuxubtik u k'aayil kuxtal.
Tumen ma' u k'aat u k'ay u kíimil.

\section{EL BÚHO}

El búho llega.

Se agazapa sobre el muro.

Medita.

Qué muerte anunciar

si ya nadie vive en este pueblo.

Los fósiles de la gente transitan a ningún lado

Pinta la luna las tumbas del camposanto

que ha comenzado a masticar maleza.

El búho

ensaya un canto a la vida.

Se niega a presagiar su propia muerte.

(CUEVAS COB, 2008, p. 15)

A coruja, ave agourenta, anunciadora de mortes, mas quais mortes se ninguém mais vive nessa cidade? Săo fósseis de gente, perambulam e só o sombrio da lua ilumina as tumbas dos cadáveres. Se por um lado, a tenebroso da morte se anuncia indelével, por outro a relaçóes entre a Morte e a vida, ou ainda o passado e o futuro possível, sâo 
evocados diante do encerramento dos ciclos que compóem a vida. Afinal, nos últimos três versos, o pássaro ensaia um canto a vida, talvez uma ponta de esperança.

Entăo, abre-se para uma nova perspectiva para a vida, apesar da presença da Morte, resiste e nega a possibilidade do fim de sua própria vida. Como também, aponta da poetisa guatemalteca de origem Maya K'iche'-Kaqchikel Rosa Chávez, em sua poesia de sobrevivência profunda em novos sentidos para sua própria condiçăo de ser mulher e ser indígena: "Sobreviví al incendio de mi cuerpo / Sobreviví el estallido de la carne/ Sobreviví a las cadenas en los tobillos/Sobreviví al fierro en mis venas / Sobreviví a la ausencia de las letras/Sobreviví al escarmiento del capataz [...]". O eu-poético ressalta seu estado de superaçâo às adversidades impostas ao próprio corpo, o incêndio, as explosōes, as correntes, săo direcionados a sua limitaçăo e morte, domínio e subjugaçâo. Săo marcas profundas da tortura e morte promovida pelo colonizador. E continua,

\author{
Sobreviví a masacres \\ sobreviví a la verdad que rebosaba de las lenguas \\ sobreviví al drama de la carne y la pólvora \\ sobreviví al amor que no cabe en una persona \\ sobreviví a la tormenta en el hueso derruido \\ sobreviví a la miserable tumba abandonada \\ sobreviví a la perdida de mis huesos florecidos \\ sobreviví al salvajismo de la civilización \\ sobreviví a tú desnudez anclada en la memoria \\ sobreviví a la bestialidad de un solo recuerdo \\ sobreviví a al exterminio del fuego sobre la montaña \\ sobreviví a la perforación \\ sobreviví a la aceptación del destino \\ sobreviví a la inseguridad ancestral \\ sobreviví a mí misma. (CHAVÉZ, s/d)
}

Sobrevida é sobre a morte, o poema de Rosa Chavéz, nos faz refletir que a sobrevivência é antes de tudo um processo de resistência, apesar das atrocidades: massacres, a pólvora, a ideia de civilizaçáo (como diz a autora: selvageria da civilizaçăo), extermínios, incêndios e, por fim, a própria condiçâo ancestral, ou seja, a si mesma. Por fim, săo versos perturbadores que nos apresenta, assim como sâo dolorosas as metáforas, através delas nos saltam a nossa consciência sobre a morte, o genocídio e a guerra que se arrebentam entre a palavra e o papel.

Quando se trata de marcas do genocídio indígena nos poemas das mulheres de Abya Yala, tracejamos um complexo percurso de barbaridades perpetradas pelo colonizador e sua herança cultural. Marcas da morte, do sangue derramado, de massacres e extermínios contra grupos étnicos e contra os corpos das mulheres. E ao tratarmos da morte, vemos o seu revés a vida ou o estado de sobrevivência. A morte pode ser considerada por muitas culturas como o fim absoluto de tudo aquilo que vive, é o aspecto destrutível e perecível da própria existência. No entanto, em tantas outras culturas, 
pode ser regeneraçăo, abrir-se ao novo como possibilidade de reinício no desconhecido, o que náo impede de se entender o sentido de morrer como algo angustiante, talvez um trânsito para uma outra existência.

É nesse sentido, que as literaturas indígenas contemporâneas estâo fincadas sob as raízes da árvore da ancestralidade, da memória e do conhecimento indígenas em formas poéticas de resistência. A também escritora indígena do povo Potiguara, Maria das Graças Ferreira Graúna, em sua voz poética expressa no poema Cançâo Peregrina: "As pedras do meu colar sâo história e memória / Do fluxo do espírito / De montanhas e riachos / De lagos e cordilheiras / De irmăos e irmás / Nos desertos da cidade / Ou no seio das florestas". (GRAÚNA, 1999, p. 27). Irmanadas em um só fio, como pedras engatadas ornando um colar, as populaçôes indígenas de Abya Yala formam um senso comunitário e integrativo, a partir das suas próprias diferenças, um colar com muitas cores de diferentes etnias que formam suas próprias histórias de resistência.

Em outro poema de Graça Graúna, Era uma vez, o texto faz uma referência metafórica ao conflito da tomada das terras indígenas pelo projeto colonial eurocêntrico que transformou o território de Abya Yala:

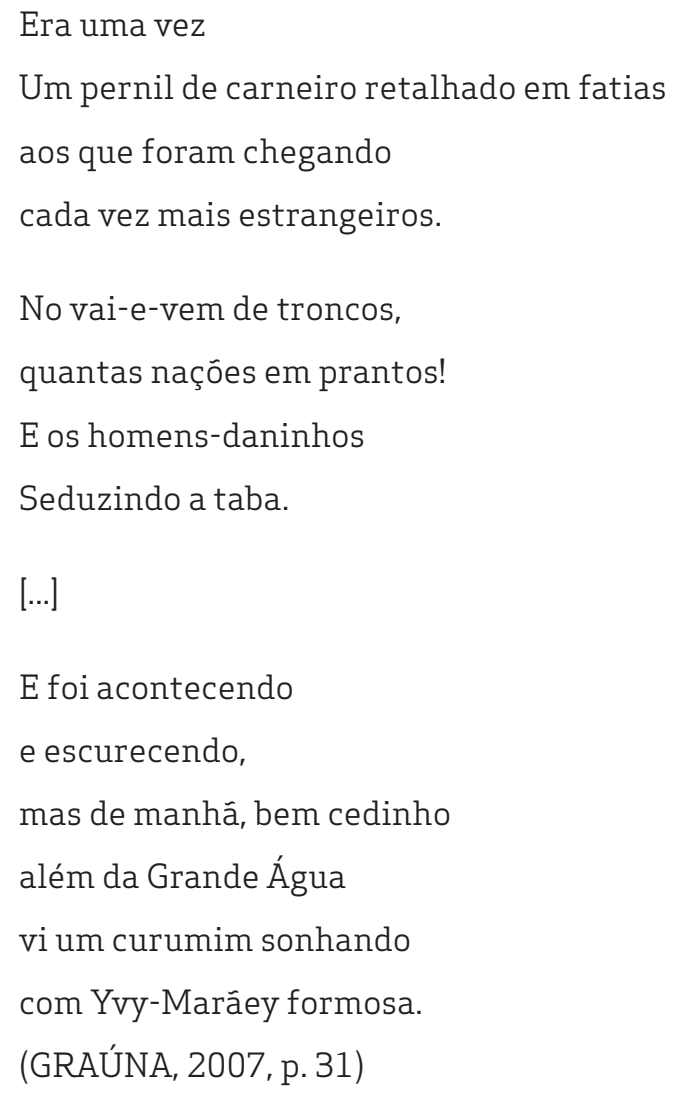

Território em retalhos, dividido, limitado pelo domínio do poderio bélico dos estrangeiros, sedutores homens-daninhos na sanha do poder. As marcas do genocídio de naçóes indígenas em prantos pelas atrocidades cometidas pelo colonizador. Graúna remonta os tempos ao trazer à tona a malícia, a falsidade, a ânsia pela guerra. Yvy-Maráey, a Terra sem Males para os tupi-guarani, a busca da terra ancestral pelo lugar em que tudo seria melhor, com um futuro reservado em uma natureza plena com a Máe Terra, o sonho e a utopia da criança que olha o horizonte em busca de 
esperança ante o caos perpetrado pelo colonizador. Os caminhos trilhados em procura de Yvy-Marăey formosa nos conduzem até a contemporaneidade na ânsia de futuro. Conforme diz Olivieri - Godet:

O fim do poema desvia do fio macabro da história e reintroduz a esperança, recorrendo a imagens que apelam para a renovaçăo e reintroduzem a utopia: "E foi acontecendo / e escurecendo, / mas de manhă, bem cedinho / além da Grande Água / vi um curumim sonhando / com Yvy-Marăey formosa.". A matéria poética busca a memória cultural indígena, fazendo brotar referências míticas e linguísticas. O poema se conclui com a imagem de uma criança indígena que sonha com a Terra sem Males, "lugar privilegiado e indestrutível, onde a terra produz seus próprios frutos e onde năo se morre" (Clastres, 1975, p. 37). O poema se apropria das palavras proféticas do mito, sugerindo um futuro em que seria possível uma reorganizaçấo social, apesar do colapso das populaçôes indígenas. (OLIVIERIGODET, 2020, pp. 60-61)

Portanto, a literatura nos proporciona perceber o elo com a nossa essência, com aquilo que desejamos, projetamos, enfim, o nosso imaginário. Projetar essa criança, que pode ser a centelha de um adulto em seu interior solicitando passagem para o novo, inscreve uma leveza nos tempos vindouros. É o curumim, a criança indígena, que vê o futuro através da projeçăo de Yvy-Marăey, a terra sem males que os tupi-guarani tanto buscaram. No entanto, náo nos basta o sonho de futuro, é preciso com coragem tecer o retorno da flecha ancestral para se reinventar, se (re)encantar, ressignificar e, sobretudo, rexistir. Partindo desse pressuposto, pensar a morte como um ciclo que por findar também se abre ao novo, e dessa forma incide no princípio do que chamamos de resistência. Assim, cabe-nos concluir que enquanto a poesia se fizer presente, a morte nâo alcançará, por isso, é preciso pensar em nossa Yvy-Marăey formosa, nâo como um fim, mas como o princípio das nossas movências poéticas carregadas de vida.

\section{À GUISA DE (IN)CONCLUSÕES}

Desde 1492, invadem as terras de Abya Yala. Desde 1500, tomam as terras das gentes da floresta da terra brasilis. Desde entăo, os saqueamentos, os extermínios e as inúmeras outras formas de opressóes săo contínuas. Como bem sabemos e breve comentamos, apesar do que se propaga sobre o fim da Colonizaçâo, nunca puseram fim aos processos coloniais, as consequências ainda podem ser sentidas pelos povos indígenas de todo o vasto território. O ressoar poético da literatura indígena se faz em torno de um canto de resistência que ressoa na contemporaneidade através das escrituras de autoras de diversos povos originários, reiteremos que o que observamos neste artigo é apenas um recorte muito limitador de vozes poéticas de três grupos étnicos.

Sendo assim, genocídio, violaçôes, injustiças, dores que compôem a ancestralidade indígena. Há morte, mas também há vida e vontade de seguir, como podemos observar no poema La vida y la muerte se hermanan, de Graciela Huinao:

De enseñanza simple era mi padre

con su naturaleza sabia.

Al hermanar la vida y la muerte 


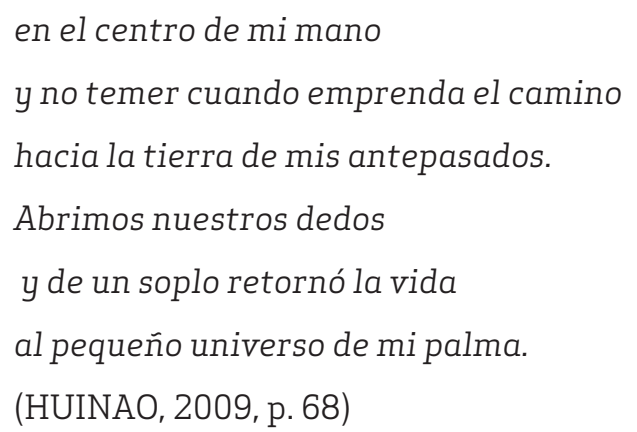

Uma ao lado da outra, como irmás, estăo a morte e a vida, unidas a voz ancestral do pai que toca a máo da filha para fazer, sem medo, crescer em sua palma a simplicidade da criaçăo, nesses ritos de passagem que săo o nascer e o morrer. A sabedoria ancestral dos mais velhos mostra que pela morte a vida também se renova, como num sopro que se retorna a vida um universo na palma da măo de quem escreve e cocria mundos. Parece-nos que a figura do pai nos releva a sabedoria daqueles que sabem que a escrita, enquanto criaçăo, é renovaçăo, é existência em resistência para năo temer criar outros mundos possíveis.

Assim, palavra proferida pela mulher ameríndia carrega em sua estrutura as vozes de seus antepassados, são sentidos, significâncias, articulaçōes sonoras e letras entrecruzadas na contemporaneidade das literaturas. Ao lermos os textos literários, percebemos como as palavras das escritoras indígenas de Abya Yala podem ser vivas e sagradas, inerentes ao seu próprio corpo, assim como também săo os elementos da natureza. E, portanto, traduzem vida e morte, dores e alegrias, anseios e resistências. Diante dessas observaçóes, a memória ancestral traspassa as veias do ser mulher indígena e ecoa palavras no tempo. A palavra, tal qual a terra, é sentimento de pertença.

Por tudo isso, que os versos poéticos escritos por mulheres indígenas de diversos grupos étnicos de Abya Yala nos remetem a resistência, mas sobretudo nos mostram a convicçăo de uma fonte ancestral em que se concentra o seu poder próprio. Elaborando, assim, um discurso que busca afastar-se da condiçấo de subalternidade. 


\section{REFERÊNCIAS}

BOSI, Alfredo. Narrativa e resistência. In: BOSI, Alfredo, Literatura e resistência. Sáo Paulo: Companhia das Letras, 2002, p. 118-135.

CHAVÉZ, Rosa, Poema de Rosa Chavéz, Metáfora, Literatura y Arte. (on-line) Disponível em: https://fipq.org/rosa-chavez-guatemala/ Publicado em: 02 de janeiro de 2017, Acesso em: 15 de maio de 2021.

CUNHA, Manuela Carneiro da. Introduçâo à história dos índios no Brasil. In: História dos Índios no Brasil. Manuela Carneiro da Cunha (org.) Cia das Letras: Sáo Paulo, 2002.

CUEVAS COB, Briceida. Ti'u billil in nook' - Del dobladillo de mi ropa. México, 2008.

GRAUNA, Graça. Canto Mestizo. Rio de Janeiro: Ed. Blocos, 1999.

GRAUNA, Graça. Contrapontos da literatura indígena contemporânea no Brasil. Belo Horizonte: Mazza Ediçōes, 2013.

GRAUNA, Graça. Tear da palavra. Belo Horizonte: S.n., 2007.

HARLOW, Barbara. Resistance Literature, Methuen Co. NY and London, 1987.

HUINAO, Graciela, El Patas Verdes. In: Hilando en la memoria: 7 mujeres mapuche: CURRIAO / HUINAO / MILLAPAN / MANQUEPILLAN/PANCHILLO / PINDA/RUPAILAF, de Soledad Falabella, Allison Ramay, Graciela Huinao (org.), Editorial Cuarto próprio, Santiago, Chile, 2006.

HUINAO, Graciela, Walinto, Editorial Cuarto Propio, Santiago -Chile, 2009.

KVYEH, Rayen, Colonizacion, in.: CURRIAO, Maribel;MORAGA, Fernanda. Kümedungun/ Kümewirin. Antología poética de mujeres mapuche (siglos XX-XXI). Caniguán, Jacqueline (versión mapudungun). Santiago de Chile: LOM, 2010.

MBEMBE, AchiIIe. Necropolítica: biopoder, soberania, estado de exceçâo, política da morte. Trad. Por Renata Santini. - Sáo Paulo: n-1 ediçōes, 2018.

MILLÁN, Moira. Mujer Mapuche: Explotación colonial sobre el territorio corporal. In.: BIDASECA, Karina \& LABA, Vanesa Vazquez (org.). Feminismos y poscolonialidad. 2a Ed. - Buenos Aires: Ediciones Godot Argentina, 2011.

OLIVIERI-GODET, Rita. Vozes de mulheres ameríndias nas literaturas brasileira e quebequense, Rio de Janeiro, Ediçôes Macunaíma, 2020.

PORTO-GONÇALVES, Carlos Walter. Entre América e Abya Yala - tensōes de territorialidades, Desenvolvimento e Meio Ambiente, Editora UFPR n. 20, p. 25-30, jul./dez. 2009.

POTIGUARA, Eliane. Metade cara, metade máscara. Rio de Janeiro, RJ - $3^{a}$ ediçáo Grumin, 2018.

QUIJANO, Aníbal. Colonialidade do poder, eurocentrismo e América Latina. In: A colonialidade do saber: eurocentrismo e ciências sociais. Perspectivas latinoamericanas. Buenos Aires: CLACSO, 2005, p. 117-142. 
TUPTURKA, Abya Yala Wawgeykuna (Hermanos Americanos), in.: MALDONADO, Beatriz Carrera \& ROMERO, Zara Ruiz (org.). Abya Yala Wawgeykun: Artes, saberes y vivencias de indígenas americano, do Instituto Zacatecano de Cultura "Ramón López Velarde". México, 2017. 